
e-ISSN 2016/Atual: 2525-7870 | e-ISSN 2015/2016: 2447-018X

\title{
Relações do trágico em Combate de negro e de cães, de Bernard- Marie Koltès: da teoria à prática
}

\author{
Relaciones del trágico em Combate de negro y perros, por Bernard-Marie \\ Koltès: teoría a la práctica
}

\section{Connections of the tragic in Combat of black and dogs, by Bernard-Marie Koltès: from theory to practice}

\author{
Lic. Lucas Ribeiro Galho ${ }^{1}$ \\ Dra. Fernanda Vieira Fernandes ${ }^{2}$ \\ Ma. Maria Amélia Gimmler Neto ${ }^{3}$
}

\begin{abstract}
Resumo
O presente trabalho tem por objetivo analisar e discutir o texto Combate de negro e de cães (1979), de BernardMarie Koltès, buscando entendê-lo como um exemplar trágico no fim do século XX. A partir da investigação acerca dos componentes dramáticos que conferem tragicidade à peça, bem como dos elementos propulsores do trágico na atualidade, tentar-se-á estabelecer um diálogo breve e inicial entre o texto (objeto de estudo do autor no trabalho de conclusão do curso de Teatro-Licenciatura da Universidade Federal de Pelotas) e a montagem do espetáculo Combate: corpos mortos, vivos e por vir, realizado pelo "Laboratório de Dramaturgismo e Direção Rotativa de Cenas" da referida instituição, coordenado pelas professoras Dra. Fernanda Vieira Fernandes e Ma. Maria Amélia Gimmler Netto. Apoiada na obra de Koltès e abordando temas pertinentes para a sociedade contemporânea, a encenação institui o racismo e o machismo como seus motores dramáticos, estabelecendo-os como importante pauta de debate.
\end{abstract}

Palavras-Chave: Bernard-Marie Koltès; laboratório; racismo; tragédia.

\section{Resumen}

El presente trabajo pretende analizar y discutir el texto Combate de negro y perros (1979), de Bernard-Marie Koltès, buscando entenderlo como un ejemplo trágico a finales del siglo XX. A partir de la investigación de los

\footnotetext{
1 (Licenciado em Estudos Artísticos; Instituto de Letras - Universidade de Coimbra; Coimbra, Portugal; Licenciado em Teatro; Centro de Artes - Universidade Federal de Pelotas; Pelotas, Rio Grande do Sul, Brasil; lucas.galho@yahoo.com.br)

2 (Doutora em Letras; Programa de Pós-graduação em Letras - UFRGS; Porto Alegre, Rio Grande do Sul, Brasil; Docente do Curso de Teatro-Licenciatura - Universidade Federal de Pelotas; Pelotas, Rio Grande do Sul, Brasil; nvnandes@gmail.com)

${ }^{3}$ (Mestre em Artes Cênicas; Programa de Pós-graduação em Artes Cênicas - UFRGS; Porto Alegre, Rio Grande do Sul, Brasil; Docente do Curso de Teatro-Licenciatura - Universidade Federal de Pelotas; Pelotas, Rio Grande do Sul, Brasil; mamelianetto@gmail.com)
} 

e-ISSN 2016/Atual: 2525-7870 | e-ISSN 2015/2016: 2447-018X

componentes dramáticos que confieren tragicidad a la pieza, así como los elementos propulsores de lo trágico en la actualidad, se intentará de establecer un diálogo breve e inicial entre el texto (objeto de estudio del autor en la obra de conclusión del curso de Teatro-Graduación de la Universidad Federal de Pelotas) y la montagem del espectáculo Combate: corpos mortos, vivos e por vir, realizado por el "Laboratório de Dramaturgismo e Direção Rotativa de Cenas" de la dicha institución, coordinados por los professores Dra. Fernanda Vieira Fernandes y Ma. Maria Amélia Gimmler Netto. Basados en la obra de Koltès y abordando temas pertinentes a la sociedad contemporánea, la puesta en escena determina el racismo y el machismo como sus motores dramáticos, estableciéndolos como una importante cuestión de debate.

Palabras claves: Bernard-Marie Koltès; laboratorio; tragedia; racismo.

\begin{abstract}
The present work aims to analyze and discuss the text Combat of black and dogs (1979), by Bernard-Marie Koltès's, seeking to understand it as a tragic example at the end of the 20th century. From the investigation of the dramatic components that confer tragicity to the piece, as well as the propellant elements of the tragic in the present time, it will be tried to establish a brief and initial dialogue between the text (object of study of the author in the course's conclusion work of Theater-Graduation of the Federal University of Pelotas) and the assembly of the show Combate: corpos mortos, vivos e por vir, realized by the "Laboratorio de Dramaturgismo e Direção Rotativa de Cenas" of mentioned institution, coordinated by the teachers Dra. Fernanda Vieira Fernandes and Ma. Maria Amélia Gimmler Netto. Based on the Koltès's work and approaching pertinent themes to contemporary society, the staging determine racism and male chauvinism as its dramatic motors, establishing them as an important question of debate.
\end{abstract}

Keywords: Bernard-Marie Koltès; laboratory; racism; tragedy.

\title{
1. Introdução
}

Um dos gêneros dramáticos mais antigos que se tem notícia, até hoje objeto de estudo entre pesquisadores literários e teatrais, é a tragédia. Entretanto, apesar de a tragédia como conhecida em seu auge na Grécia do século V a.C. já não existir mais, a sua essência atravessou o tempo, adaptando-se e transformando-se, de maneira que resquícios dos elementos constituintes da tragédia helênica podem ser observados na dramaturgia moderna e contemporânea. Partindo da ideia desenvolvida pelo teórico e crítico inglês Raymond Williams de que "por meio dela [a tragédia] compreendemos muitas vezes mais a fundo o contorno e a conformação de uma cultura específica" (WILLIAMS, 2002, p.69), ler-se-á o texto koltesiano e a montagem de Combate como um retrato da nossa sociedade que expõem, através da lente da tragédia, alguns de seus problemas e necessidades mais urgentes.

Inicialmente o artigo debruça-se sobre aspectos relevantes da tragédia grega, visando estabelecer um pequeno paralelo entre o sentido do trágico na sua origem e o trágico que se aborda tanto no texto koltesiano, quanto na montagem de Combate: corpos mortos, vivos $e$ por vir. Na sequência, faremos uma sucinta apresentação de Bernard-Marie Koltès, passando, depois à reflexão sobre alguns dos elementos trágicos clássicos que estão presentes na peça de Koltès (coro e hybris). Por fim, certos aspectos acerca da montagem do "Laboratório de Dramaturgismo e Direção Rotativa de Cenas" serão esboçados, principalmente enfocando no 
que o grupo considera como o tema trágico da contemporaneidade levado à cena: o machismo e o racismo.

\section{A tragédia grega}

A tragédia grega é uma das mais antigas formas de arte conhecidas pela humanidade. É também, considerada por muitos autores, o marco inicial do teatro ocidental, sendo revisitada de tempos em tempos até os dias de hoje. No entanto, foi no ano de 534 a.C., mais precisamente no mês de março, que Pisístrato, o atual governante de Atenas ordenou que Téspis - um ator proveniente da ilha de Icária - participasse da Grande Dionisíaca daquele ano. Foi durante sua apresentação no referido festival que Téspis estabeleceu uma nova forma de "representação": ao se destacar do coro báquico e estabelecer um diálogo com o corifeu, ele instaurou o papel do hypokrites, ou seja, aquele que responde, modificando de forma irreversível o modo de se pensar o rito e escrevendo um novo capítulo da história da civilização: “dessa inovação, primeiramente não mais do que um embrião dentro do rito do sacrifício, se desenvolveria mais tarde na tragédia, etimologicamente, tragos (bode) e ode (canto)" (BERTHOLD, 2010, p.105).

A partir de então, a tragédia foi se desenvolvendo e aperfeiçoando, passando a ocupar um importante espaço nas celebrações ritualísticas e nos festivais em homenagem aos deuses na pólis. No século $\mathrm{V}$ a.C., a tragédia helênica alcança o seu apogeu, com a construção de prédios específicos para a sua representação, visto que antes disso, as apresentações eram realizadas na Ágora. Após esse período de magnificência da tragédia, a Grécia atravessou um período de turbulência que corresponde à guerra do Peloponeso, após a qual enfrentou uma crise financeiro-político-religiosa onde a soberania dos deuses foi posta em causa e o racionalismo ganhou força entre os cidadãos gregos, fazendo com que o domínio da razão se sobrepusesse ao domínio do mito. Com isso, a tragédia grega que possuía no seu íntimo uma forte ligação com os deuses e a religião começou a perder força, deixando para história o legado do seu período auge onde tão bem representou o espírito da sociedade helênica.

Apesar de a tragédia como conhecida em seu auge na Grécia do século V a.C. já não existir mais, a sua essência, o 'espírito trágico', atravessou os séculos que se seguiram adaptando-se e transformando-se de maneira que resquícios dos elementos constituintes da tragédia grega podem, ainda hoje, ser observados na dramaturgia moderna e contemporânea.

\section{Breves informações sobre Bernard-Marie Koltès}



e-ISSN 2016/Atual: 2525-7870 | e-ISSN 2015/2016: 2447-018X

Nascido a 9 de abril de 1948 na cidade de Metz, na França, Bernard-Marie Koltès era parte de uma típica família católica e burguesa europeia. Filho de pai militar, Koltès não teve muito convívio com a figura paterna, falta que era compensada pelos livros que o mesmo lhe enviava quando estava distante, em alguma missão, fato que estabeleceu uma grande intimidade do autor com o mundo das letras, em especial com os clássicos.

Em 1967, ingressou na faculdade de jornalismo, e um ano mais tarde, em maio de 1968, devido à uma greve geral que rapidamente alcança proporções revolucionárias, Koltès abandonou a França em direção ao Canadá, e logo em seguida para Nova Iorque. De acordo com Fernandes, "na badalada cidade norte-americana, Koltès amadureceu, experimentou substâncias entorpecentes sem preocupar-se com limites e precauções e viveu diversas aventuras sexuais - que lhe causaram uma série de doenças venéreas" (FERNANDES, 2014, p.123).

Em 1970, de volta a Estrasburgo, após assistir à uma representação da atriz Maria Casarès no espetáculo Medeia, de Sêneca, fundou a companhia Théâtre du Quai, onde escreveu os textos de Les Amertumes e La Marche, entre outros.

Koltès realizou diversas viagens a países como Guatemala, Nicarágua, Nigéria, onde sua descrença pelos valores ocidentais se acentua, estimulando assim o seu "refinado cinismo literário" (COELHO, 2009, p.4). Em 1977, o autor escreve o monólogo La Nuit juste avant les florêts, obra apresentada pelo ator Yves Ferry no Festival de Avignon e que marca o início de uma nova fase na escrita de Koltès, mais madura e significativa. Segundo Fernandes:

La Nuit juste avant les forêts é seu primeiro grande e verdadeiro texto, devido à temática, à construção (monólogo sem ponto, de uma frase só) e à linguagem (ora violenta, ora poética; repleta de metáforas e imagens). Nele, percebem-se os rumos que tomaria a sua dramaturgia. Foi também essa peça que deu pela primeira vez alguma notoriedade ao autor, quando da montagem em 1981, em Paris, no Petit Odéon (na época pertencente à Comédie-Française), com atuação de Richard Fontana e direção de Jean-Luc Boutté. (FERNANDES, 2014, p.125-126)

A partir de 1983, Koltès estabeleceu uma parceria com o encenador Patrice Chéreau, responsável pelas montagens de Combat de nègre et de chiens (1983), Quai Oest (1986), Dans la solitude des champs de coton (1987) e Retour au désert (1988). Ainda durante este estágio, o autor escreve Tabataba, além de traduzir a obra Le Conte d'hiver, de Shakespeare. Sobre esta fase, Coelho afirma que:

Esta cumplicidade e diálogo electivo marcarão a recepção da obra de Koltès, diluindo-se sistematicamente as fronteiras autorais entre encenador e dramaturgo. 
Paradoxalmente, serão as encenações de Chéreau que catapultarão o alcance da sua obra, sendo encenada um pouco por todo o mundo. (COELHO, 2009, p.4)

É ainda no ano de 1983 que Koltès começou a sofrer os sintomas da AIDS, doença que ainda viria a ceifar a sua vida. Em 1988, com o estágio da doença mais avançado e após diversas viagens que estimularam toda a sua escrita, o autor terminou a sua última obra, Roberto Zucco, inspirada pela figura do assassino italiano Roberto Succo. Em 15 de abril de 1989, Koltès faleceu, aos 41 anos de idade. No entanto, sua obra alcançou rapidamente o sucesso, o que aconteceu logo após a sua morte. De acordo com Coelho:

\begin{abstract}
Rapidamente tornada um clássico dos repertórios modernos, a obra de Koltès constrói perigosas fábulas habitadas pelo enigma. As metáforas que apresenta são terrivelmente descrentes do mundo ocidental e cinicamente críticas do modo como o homem habita e se relaciona no mundo contemporâneo. Simultaneamente, revelam um autor atento às desigualdades do planeta e às pulsões mais íntimas do sujeito criativo. (COELHO, 2009, p.5)
\end{abstract}

Após a sua morte, a obra de Koltès foi traduzida para inúmeros idiomas, e se estabeleceu como um exemplar importante da dramaturgia contemporânea, fruto de um autor polêmico que encontrou no teatro uma forma de dar voz a problemas e assuntos relevantes da sociedade moderna.

\title{
4. Elementos trágicos clássicos observáveis no texto koltesiano
}

\subsection{O Coro}

Um dos principais componentes da tragédia, presente desde os seus primórdios e que se estabeleceu como característica reconhecível do gênero trágico é o coro. No entanto, a forma coral era um recurso também utilizado nas comédias, ditirambos e dramas satíricos, fazendo parte, na era clássica, de todos os gêneros dramáticos, pois combinava "aspectos de ordem mimética, narrativa, festiva, estética e simbólica" (ANDRADE, 2013, p.69). Ainda que o coro tenha entrado em decadência no final do período clássico, sua presença pode ainda hoje ser observada em diversos dramas modernos e contemporâneos, não na sua matriz original, mas reorganizado de forma a melhor se adaptar ao modelo de escrita moderno.

Apesar de o coro nas tragédias gregas possuírem uma forma bem característica, a presença dele no texto koltesiano não se dá de forma tão explícita, tampouco se apresenta como uma variação da forma coral clássica. Em Combate de negro e de Cães, existe um coletivo de personagens, os guardas, que possuem alguns elementos de identificação com o coro trágico helênico. No entanto, os soldados de Koltès permanecem na periferia da ação 

e-ISSN 2016/Atual: 2525-7870 | e-ISSN 2015/2016: 2447-018X

dramática até o fim da peça, ocupando as guaritas de proteção do canteiro de obras públicas em que trabalham. Eles exercem papel fundamental na construção da linha dramática do texto na medida em que são eles que permitem a entrada de Alboury no canteiro de obras para que o mesmo possa reivindicar o corpo de seu irmão morto:

\begin{abstract}
ALBOURY - Impossível, senhor. Olhe os guardas, olhe para eles, lá no alto. Eles vigiam tanto dentro do campo quanto fora, eles olham pra mim, senhor. Se eles me virem sentar com o senhor, eles vão desconfiar de mim; eles dizem que é preciso desconfiar de uma cabra viva na toca do leão. Não fique zangado com o que eles dizem. Ser um leão é de longe mais respeitável do que ser uma cabra.

HORN - No entanto, eles deixaram o senhor entrar. É preciso um livre-passe, geralmente, ou ser representante de alguma autoridade; eles sabem muito bem disso. (KOLTÈS, 2010, p.26)
\end{abstract}

Além de autorizar a entrada de Alboury, o coro é responsável pela morte de Cal:

"Cal é primeiro ferido no braço; ele larga o fuzil. No alto de uma guarita, um guarda abaixa sua arma; de outro lado, outro guarda levanta a sua. Cal é ferido na barriga, depois na cabeça; ele cai. Alboury desapareceu. Breu.” (KOLTÈS, 2010, p.116).

Este acontecimento é fundamental para a construção da narrativa.

De acordo com Andrade, Schlegel propõe uma leitura onde coro era visto como um “espectador ideal, uma espécie de árbitro ou juiz que comentava a ação dramática, não se envolvendo nela" (ANDRADE, 2013, p.70). Todavia, a construção coral criada por Koltès vai além da simples observação passiva e parte para ação efetiva, configurando-se, de acordo com o modelo esquiliano ${ }^{4}$, como importante ferramenta na criação e desenvolvimento da ação dramática.

Embora o coro no texto de Koltès esteja desconstruído, ele ainda possui algumas características gerais que o liga diretamente com a matriz grega. Primeiramente, temos o caráter coletivo representado por esse personagem que pode ser observado nos soldados africanos, que de forma geral representam instâncias sociais que por sua vez correspondem à voz de um coletivo de pessoas. Se por um lado "para os gregos, não era possível a existência de um herói sem o coro, já que a sua força dependia em larga medida do coletivo coral" (ANDRADE, 2013, p.70-71), por outro lado, essa força se encontra ainda presente na dramaturgia contemporânea, não na figura de um herói, mas sim de uma narrativa, que sem a presença do coro perde a potência dramática e trágica.

\footnotetext{
${ }^{4}$ Os coros desenvolvidos por Ésquilo eram construídos como parte importante e central da ação - como pode ser observado na tragédia Coéforas -, característica essa que começa a perder sua força na dramaturgia de Sófocles e Eurípides.
} 
De acordo com Wilson, o coro "foi seguramente uma presença dominante na tragédia - física e estética - e que, ao contrário dos atores, quase nunca abandonava o espaço cênico, onde entrava praticamente no início da peça" (WILSON apud ANDRADE, 2013, p.70). O coro analisado neste estudo, da mesma forma como o clássico, é presença constante durante todo o texto dramático, embora nem sempre ele esteja participando ativamente da ação.

Em Combate de negro e de cães, como dito anteriormente, a participação do coro se dá de forma mais operacional, executando intervenções físicas diretamente na cena, ou através de diálogos que não influenciam na dramaturgia, como descrito nas rubricas de cena: "em meio a um profundo silêncio, dois guardas se interpelam bruscamente, brutalmente; depois o silêncio volta" (KOLTÈS, 2010, p.71); "CAL - O que é que interessa a ele, em você? (Chamados dos guardas; silêncio)" (KOLTÈS, 2010, p.53).

Uma outra característica observável no coro koltesiano, é uma forte identidade de gênero atribuída a ele, já que o mesmo é constituído estritamente pela presença masculina. Este aspecto peculiar é importante na medida em que essa informação caracteriza um modus operandi relacionado à natureza do gênero masculino. Ou seja, através do coro, são reveladas particularidades que explicitam, por meio de ações e uso de objetos que são geralmente atribuídos ao gênero masculino, um reflexo dessa categorização preconcebida.

Conforme o coro dos soldados se manifesta como uma presença extremamente ameaçadora aos personagens da obra, estabelecendo um ambiente de tensão que permanece durante quase todo o texto, fica evidente um comportamento violento e volátil, muitas vezes outorgado ao sexo masculino. Não obstante, somando-se a esse modo de agir, nos deparamos com os objetos manipulados por esses personagens que, mais uma vez, reforçam a importância de gênero presente na sua construção.

Amplificando sua presença ameaçadora e o seu papel de dominação no drama, os guardas de Koltès empunham armas de fogo, instrumento que possui a capacidade de materializar o poder de opressão que está intimamente conectado ao papel exercido pelo homem na história. Segundo o dicionário de símbolos de Jean Chevalier e Alain Gheerbrant, “a psicanálise vê na maioria das armas um símbolo sexual... A designação do órgão masculino é a mais clara" (CHEVALIER; GHEERBRANT, 2006, p.81), dessa forma, a masculinidade é representada pelo poder que está relacionado ao porte desse objeto que indica um caráter mais ativo, de postura agressiva, exatamente como se apresenta o comportamento do coro de soldados no texto. Dessa forma, a arma utilizada pelo coro reflete de forma efetiva o papel social que o gênero masculino ocupou durante um longo tempo na história e que, ainda hoje, se encontra enraizado no inconsciente de grande parte da população. 


\subsection{A Hybris}

Outro elemento fundamental para a construção trágica clássica é a hybris, que na tragédia grega significa o excesso, a desmedida cometida pelos mortais e que é passível de castigo por parte dos deuses, é um dos motores que ativam a tragicidade e consequentemente, a katharsis. É ela também um dos aspectos mais abordados pelos tragediógrafos, se constituindo como um dos elementos que leva o herói trágico a percorrer o caminho da felicidade ao infortúnio, proposto por Aristóteles. De acordo com a definição encontrada no dicionário de Patrice Pavis onde se estabelece que "a hybris leva o herói a agir e provocar os deuses, apesar de seus avisos, o que vai dar na sua vingança e na sua perda" (PAVIS, 2011, p.197), percebe-se que este conceito está intimamente ligado ao herói trágico, que no texto de Koltès se encontra fragmentado entre os quatro personagens do drama.

Em Combate de negro e de cães, a hybris pode ser detectada e relacionada, de acordo com a definição de Pavis, a três personagens da trama escrita por Koltès. Se para Pavis a hybris se configura com uma desmedida que necessariamente acarreta a quem a praticou ${ }^{5}$ uma perda, um sofrimento, Cal, Horn e Léone são os representantes de Koltès para essa definição. Apesar de os quatro personagens sofrerem algum tipo de perda durante o drama (Alboury perde o seu 'irmão'; Horn, sua companheira e seu colega de trabalho; Cal, sua vida e Léone o amor de Horn e o possível casamento com o mesmo), apenas as perdas de Cal, Horn e Léone são acarretadas por uma ação impulsiva realizada diretamente por eles.

Dos três personagens, Cal é o mais instável emocionalmente. Por diversas vezes, o operário se deixa levar por seus medos e não consegue controlar seus nervos que estão sempre à flor da pele, fato que fundamenta suas ações impetuosas e que é, por várias vezes, reconhecido por ele:

CAL - [...] Eu, o que é que eu sou? Nada. Eu sou: nada, não tenho vergonha de dizer. Fora você: nada de nada. Você não tem medo de nada; nem os canas te assustam. Eu, ao contrário, fora você, pois bem... tenho medo, não tenho vergonha de dizer. Medo, mas medo mesmo; diante de um cana negão, eu corro; é assim que é: diante de um negão que não seja cana, eu atiro. É uma questão de nervos, o medo, não dá pra fazer nada. Até diante de uma mulher eu ficaria em pânico, velho, sou bem capaz disso. (KOLTÈS, 2010, p.67)

\footnotetext{
${ }^{5}$ Apesar de Pavis relacionar a hybris diretamente ao herói trágico, nesse estudo ela será analisada à luz de todos os personagens, visto que nessa tragédia moderna, a presença do herói trágico como configurado por Aristóteles e pelas tragédias gregas não encontra equivalência direta.
} 

e-ISSN 2016/Atual: 2525-7870 | e-ISSN 2015/2016: 2447-018X

Apesar de possuir um grau mais elevado de estudos que Horn e se sentir superior aos negros que trabalham no canteiro de obras, é justamente por conta de suas ações incontroláveis e da sua incapacidade de resolver problemas pacificamente, ou seja, sua hybris, que Cal não consegue se igualar a seu superior, sendo apenas um subalterno no canteiro de obras francês. Não obstante, é devido a um impulso incontrolável de Cal ocorrido anteriormente à ação da peça, fato que desencadeia uma sucessão de acontecimentos trágicos, que a trama do texto se desenrola. Essa ação é narrada a Horn pelo próprio Cal que, após tentar inutilmente se inocentar do caso, assume a culpa e conta o que havia acontecido:

CAL - [...] O cara, Horn, posso dizer isso a você, nem era um operário de verdade; um reles boia-fria; ninguém o conhece, ninguém vai falar disso. Aí ele quer ir embora; eu digo: não, você não vai embora. [...] Aí ele cospe no meu pé e vai embora [...] esse aí eu não vou conseguir deixar ele em paz. O instinto, Horn, os nervos. Eu não o conhecia; ele tinha só cuspido a dois centímetros dos meus sapatos [...]. Então eu coloquei ele dentro do caminhão, fui até o vazadouro e joguei ele lá do alto: é só isso que você merece e pronto; e aí voltei pra casa; (KOLTĖS, 2010, p.36-39)

O assassinato de Nouofia (operário negro), causado pela instabilidade de Cal que se sentindo ofendido pelo cuspe proferido pelo africano o matou, foi o estopim inicial que acabou culminando em sua própria morte. O ‘castigo divino' veio do alto, literalmente, pois foi das guaritas de proteção do canteiro de obras, onde os guardas africanos responsáveis pela segurança do local se encontravam, que os tiros que mataram Cal foram disparados.

Em oposição ao descontrole deste personagem, Horn surge com uma tentativa diplomática de resolver o problema causado por Cal. No entanto, apesar de o personagem acreditar que conseguirá dissolver o negro de sua busca através da utilização da bebida e do seu poder de convencimento, ele se mostra extremamente arrogante e prepotente. A hybris de Horn, portanto, está intimamente ligada à sua crença de que todos têm seu preço (não apenas no sentido monetário), tanto as mulheres quanto os africanos, sendo ele capaz de utilizar artimanhas para conseguir o que deseja. Porém, é justamente a tentativa de subornar Alboury que desencadeia o fim trágico tanto de Horn, quanto de Léone, pois ao pedir que o africano aceite o dinheiro do engenheiro em troca do corpo de Nouofia, a mulher faz com que o negro perca toda a aparente calma que até então ele vinha demonstrando.

Vinda da França por meio de um convite feito por Horn que lhe ofereceu uma passagem a África para que visse uma queima de fogos de artifício, Léone é a única mulher no texto de Koltès, caracterizando-se como um foco de interesse dos três homens da peça. Ela demonstra um grande fascínio pela África, todavia, isso advém de uma visão estereotipada do 
continente africano, tipicamente eurocêntrica. Esse seu fascínio pela África exótica pode ter sido o responsável pelo encantamento imediato que Léone sentiu por Alboury. Apesar de possuir um compromisso com Horn, como pode ser visto na seguinte passagem: "ALBOURY [para Léone] - O velho me disse que você era dele" (KOLTÈS, 2010, p.83), Léone sente uma atração inevitável por Alboury, o que faz com que ela acredite que pertença à mesma realidade que a dele:

LÉONE - Não sou realmente um branca, não. Oh eu já estou tão habituada a ser o que não se deve ser, não me custa nada ser crioula ainda por cima de tudo isso. Se for por isso, Alboury, minha brancura, já cuspi nela há muito tempo, já a joguei, não quero mais. (KOLTÈS, 2010, p.102)

Léone deseja tornar-se alguém que ela não é, possuindo uma outra cor que não a sua. Este desejo de Léone, de querer fazer parte de algo, de se sentir deslocada em seu lugar origem, faz com que ela tente buscar em Alboury e em sua cultura um lugar para habitar, existir. Entretanto, o africano não abre possibilidades para um possível envolvimento amoroso com Léone e o relacionamento entre eles não se desenvolve, pois ele respeita o fato de ela "pertencer" a outro homem. Ignorando a recusa de Alboury às suas investidas, Léone tenta uma última vez conquistar o africano:

LÉONE - Eu juro: quando você voltar para casa, irei com você; enquanto eu vir você dizer: minha casa, eu direi: minha casa. A teus irmãos eu direi: irmãos. A tua mãe: mãe! Tua aldeia será a minha, tua língua será a minha, tua terra será minha terra, e até no teu sono, eu juro, até na tua morte, eu ainda te seguirei. (KOLTÈS, 2010, p.103)

Porém, Léone é rejeitada por Alboury, que vê nela apenas mais uma branca tentando corrompê-lo, pois antes dessa declaração, Léone tenta convencê-lo, assim como Horn, a aceitar dinheiro em troca do corpo de seu irmão, o que para Alboury é inaceitável.

Após ser rechaçada por ele e, consequentemente por Horn que vê em seu ato uma traição bem como uma vergonha para os brancos, Léone mutila-se no rosto com um caco de vidro, para que dessa forma obtenha a mesma cicatriz que os membros da tribo de Alboury possuem. O castigo para sua hybris se consolida com a volta dela para Paris após ter abandonado tudo no país europeu, sem nenhum dos possíveis relacionamentos que poderiam se desenvolver, da mesma forma com que perdeu tudo o que poderia ter conseguido se não tivesse desejado um outro homem, ferindo assim o compromisso pré-estabelecido com Horn.

Ainda que, como visto anteriormente, a hybris esteja relacionada diretamente com o herói trágico, a peça de Koltès não possui em sua esteira de personagens nenhum que possua os atributos para ocupar esse espaço. Primeiramente, é importante compreender o significado 
do termo herói. De acordo com o dicionário de Pavis, o herói pode ser divido em três tipos: o "herói, grau zero", o "herói clássico" e o "anti-herói". Vamos nos ater, no entanto, na definição utilizada por Aristóteles de herói trágico, que para Pavis, só existe "no sentido estrito, numa dramaturgia que apresenta as ações trágicas de reis ou príncipes, de modo que a identificação do espectador se realize em direção a um ser mítico ou inacessível" (PAVIS, 2011, p.193). Essa definição vai ao encontro com o que Aristóteles, em sua Poética, designa como algo importante a ser observado na tragédia. Para o estagirita:

\begin{abstract}
(...) é evidente, em primeiro lugar, que se não devem representar os homens bons a passar da felicidade para a infelicidade, pois tal mudança suscita repulsa, mas não temor nem piedade; nem os maus a passar da infelicidade para a felicidade, porque uma tal situação é de todas a mais contrária ao trágico, visto não conter nenhum dos requisitos devidos, e não provocar benevolência, compaixão ou temor; nem tão pouco os muito perversos a resvalar da fortuna para a desgraça. [...] Restam-nos então aqueles que se situam entre uns e outros. Essas pessoas são tais que não se distinguem nem pela sua virtude nem pela justiça; tão pouco caem no infortúnio devido à sua maldade ou perversidade, mas em consequência de um qualquer erro, integrando-se no número daqueles que gozam de grande fama e prosperidade, como Édipo e Tiestes, ou outros homens ilustres oriundos de famílias com esse mesmo estatuto. (ARISTÓTELES, 2011, p.60-61)
\end{abstract}

É evidente que nenhum dos personagens do texto estudado nessa exegese podem se enquadrar nessa definição. Entretanto, a ideia central de o texto possuir um personagem que cometa um erro (através da hybris) e, por consequência, caia em desgraça provocando no espectador a catarse, permanece como um dos elementos essenciais para a construção da narrativa trágica. No entanto, fica claro que no texto aqui estudado, o herói trágico está configurado de uma outra forma, compreendendo outros aspectos que contribuam para a narrativa contemporânea. Em Combate de negro e de cães, os personagens se apresentam de forma equiparada no que concerne ao protagonismo do mesmo. Alboury, Cal, Horn e Léone são igualmente protagonistas do drama de Koltès. Desta forma, podemos encontrar fragmentos da concepção de herói trágico espalhados entre vários personagens do drama e não, como na tragédia antiga, contidos em um único personagem.

De acordo com Raymond Williams, "a mais comum interpretação da tragédia a vê como uma ação na qual o herói é destruído" (WILLIAMS, 2002, p.79), ou seja, a construção do trágico possui ligação direta com a concepção clássica do herói. Todavia, essa figura já não corresponde à definição grega, possuindo na tragédia moderna um outro significado. Se Alboury é um dos únicos personagens que possui algumas características que possibilitem sua leitura como herói trágico através de um viés clássico, paradoxalmente, é também a partir 
RELACult - Revista Latino-Americana de Estudos em Cultura e Sociedade

Revista Latinoamericana de Estudios en Cultura y Sociedad | Latin American Journal of Studies in Culture and Society

V. 03, ed. especial, ago., 2017, p. 29-43 | relacult.claec.org e-ISSN 2016/Atual: 2525-7870 | e-ISSN 2015/2016: 2447-018X

dele que essa leitura não se concretiza, pois o personagem não sofre a destruição preconizada por Aristóteles e ressaltada por Williams.

\section{Da teoria à prática: a montagem teatral e a revelação do trágico na discussão de temas contemporâneos}

Combate: corpos mortos, vivos e por vir é o resultado do processo de trabalho realizado pelo "Laboratório de Dramaturgismo e Direção Rotativa de Cenas", vinculado à Universidade Federal de Pelotas, e possui como premissa a discussão, através da arte, de temas pertinentes à sociedade contemporânea. A dramaturgia que compõe o espetáculo é composta por fragmentos da referida obra de Koltès, bem como por poesias de Angélica Freitas (Um útero é do tamanho de um punho), depoimentos dos artistas criadores, estatísticas, reportagens de jornais e revistas, pontos de umbanda, canções brasileiras, etc. e foi produzida por Fernanda Vieira Fernandes, no que concerne a sua pesquisa sobre dramaturgismo.

O texto de Combate ressalta dois elementos intrínsecos à peça de Koltès que se estabelecem na montagem como motor dramático e trágico: o racismo e o machismo. Presente de forma latente em Combate de negro e de cães, o racismo se faz presente na encenação, para além dos recortes do drama koltesiano, através de depoimentos pessoais dos artistas que compõem o grupo. Partindo desses relatos e apoiado nas palavras de Koltès, o espetáculo se propõe a discutir o racismo através das cenas de embate entre o personagem Alboury, representante da coletividade negra, e de Horn, personificador do branco opressor e colonizador, buscando trazer à luz o racismo e os jogos de poder exercidos em ambientes de trabalho, especificamente, num canteiro de obras.

Ajudando a criar essa atmosfera de reflexão, a cultura afro se faz presente na montagem por meio do uso de instrumentos de percussão, da utilização de pontos de umbanda e da ocupação, no prólogo do espetáculo, da senzala desativada de um antigo casarão em Pelotas, Rio Grande do Sul. Todos esses elementos surgem como catalisadores e amplificadores da questão racial, buscando despertar no espectador, através dos ambientes, sons e imagens, uma reflexão acerca dos conceitos preconcebidos enraizados na nossa sociedade.

Não obstante, o machismo desponta na montagem como uma segunda questão, não menos importante, a ser discutida. Existe a presença de um coro, mas agora de mulheres, na encenação, contrapondo-se ao equivalente masculino do coro de guardas que Koltès insere na trama. São as mães e mulheres que vêm para dar sepultamento ao corpo do operário morto e 
não o encontram. As mulheres que conduzem o público para o momento de libertação final de Léone ao fim do espetáculo. Em outra cena, intitulada pelo grupo como "Cabra-cega", uma mulher é vendada e abordada por três homens que a encurralam enquanto os mesmos proferem trechos do texto de Koltès. Em uma alusão ao abuso que milhares de mulheres sofrem todos os dias em diversos âmbitos, a cena explicita preconceitos entranhados, revelando a urgência do debate sobre essas questões.

Há ainda um momento em que uma atriz declama trechos dos poemas Um útero é do tamanho de um punho e Mulher de vermelho, da poeta pelotense Angélica Freitas, enquanto o dorso, de duas outras mulheres, pende por duas janelas do Casarão. A poesia uterina de Freitas surge como um elemento de resistência, de luta, de questionamento, buscando revelar a força e independência feminina livre dos padrões impostos pela sociedade patriarcal.

Enquanto o racismo pode ser observado de forma latente no drama koltesiano, o machismo se revela nas entrelinhas, a medida em que a trama vai se desenrolando. Entretanto, na montagem Combate, ambos os temas se equiparam, se atravessam e se complementam, mostrando a atualidade dos temas abordados na peça de Koltès.

\section{Considerações finais}

Este primeiro artigo visando articular os aspectos teóricos estudados no Trabalho de Conclusão de Curso do autor com as questões da montagem prática do grupo de pesquisa da UFPel, é um esboço inicial sobre o tema. Novas e aprimoradas ideias surgirão quando forem se aprofundando estes limites entre teoria, dramaturgia e encenação no projeto. As apresentações públicas também ampliarão o escopo dos estudos e análises possíveis, visto que a recepção se configura como um importante veículo para perceber estes resquícios do trágico que habitam os sujeitos da sociedade atual. A estreia de Combate: corpos mortos, vivos e por vir foi realizada em 15 e 16 de outubro de 2016, em duas sessões, cada uma delas para 35 pessoas (o espetáculo tem capacidade de público restrito por conta de sua concepção).

Embora o texto de Koltès, origem primeira do trabalho, não tenha suas raízes na tragédia grega, ele pode ser lido como um exemplar trágico na contemporaneidade na medida em que, como visto acima, explora e expõe temas atuais e intrínsecos à sociedade em que está inserido. Da mesma forma que a tragédia grega se configurou como um retrato dos amores e dores da Grécia do século V a.C, o texto koltesiano se mostra como um paralelo atual, trazendo elementos presentes na configuração trágica clássica, bem como instaura novos componentes que se revelam como propulsores do trágico na modernidade. O machismo e 
racismo se descolam do texto de Combate de negro e de cães, invadindo a cena e se mostrando como essencial pauta de debate e reflexão.

São essas as tragédias reveladas por Koltès, isentas de moralismos, mas postas à disposição do público, que o espetáculo Combate: corpos mortos, vivos e por vir busca potencializar através da linguagem cênica. Mantém-se a força do coletivo dos coros, mantémse a desmedida da hybris que leva os sujeitos a assassinarem seus colegas de trabalho por motivos étnicos ou de desentendimentos fúteis. Que as tragédias de hoje possam ganhar cada vez mais espaço de debate, e que sejam, assim como na tragédia clássica, pontos de reflexão e análise na busca de uma sociedade mais justa para todos.

\section{Referências}

ANDRADE, C. Coro: corpo coletivo e espaço poético - Intersecções entre o teatro grego antigo e o teatro comunitário. Coimbra: Universidade de Coimbra, 2013.

ARISTÓTELES. Poética. Lisboa: Fundação Calouste Gulbenkian, 2011.

BERTHOLD, M. História mundial do teatro. São Paulo: Perspectiva, 2010.

BURGESS, A. A literatura inglesa. São Paulo: Ática, 2001.

CHEVALIER, J.; GHEERBRANT, A. Dicionário de símbolos. Rio de Janeiro: José Olympio, 2006.

COELHO, R. P. Inesgotável Koltès - Dois ensaios sobre Na solidão dos campos de algodão de Bernard-Marie Koltès. 2009. Disponível em:

<http://repositorio.ipl.pt/bitstream/10400.21/201/1/inesgotav el_koltes.pdf>. Último acesso: 07 de out. de 2015.

ÉSQUILO. Suplicantes. Coimbra: FESTEA - Tema Clássico, 2012.

FERNANDES, F. V. O personagem negro na literatura dramática francesa do século XX: La Putain respectueuse, de Jean-Paul Sartre, e Combat de nègre et de chiens, de Bernard-Marie Koltès. 2014. 234 f. Tese (Doutorado em Letras) - Programa de Pós-graduação em Letras, Universidade Federal do Rio Grande do Sul, Porto Alegre. 2014.

GALHO, L.R. O trágico em Anjo Negro de Nelson Rodrigues e Combate de Negro e de Cães de Bernard-Marie Koltès: Possibilidades de Leitura. 2015. Trabalho de conclusão de curso Faculdade de Teatro Licenciatura, Universidade Federal de Pelotas, Pelotas, 2015. Disponível em: <http://wp.ufpel.edu.br/teatro/files/2015/12/TCC-Lucas-DIGITAL.pdf>. Último acesso: 09 de nov. de 2016.

KITTO, D.D.F. A tragédia grega - Volume I. Coimbra: Coimbra, 1990.

KOLTÈS, B.-M. Combate de negro e de cães; Retorno ao deserto; Tabataba. São Paulo: Aliança Francesa: Instituto Totem Cultural: Imprensa oficial do estado de São Paulo, 2010. 

e-ISSN 2016/Atual: 2525-7870 | e-ISSN 2015/2016: 2447-018X

NASCIMENTO, A. do. O tempo e o modo do Brasil: Teatro do negro no Brasil - Uma experiência sócio-racial. Rio de Janeiro: Civilização Brasileira, 1968.

PAVIS, P. Dicionário de teatro. São Paulo: Perspectiva, 2011.

WILLIAMS, R. Tragédia moderna. São Paulo: Cosac Naify, 2002. 